\title{
Fertility Improvement in Subfertile Cows by Different Hormonal Protocols in Special Reference to HF Crosses
}

\author{
H. Raju*, S. Munda and P.C. Mishra
}

All India Co-ordinated Research Project on Nutritional and Physiological Approaches for Enhancement of Reproductive Efficiency in Animals CVSc \& AH, OUAT, Bhubaneswar-751003, Odisha, India

*Corresponding author

\section{A B S T R A C T}

Keywords

HF cattle,

Hormonal protocol,

Fertility, Estra

double synch,

double synch

\section{Article Info}

Accepted:

06 May 2018

Available Online:

10 June 2018
Three different hormonal protocols were tried in HF animals $(n=36)$ in coastal and western districts of Odisha for their response. The group treated with estra double synch protocol yielded highest conception rate of $50 \%$ followed by $41.66 \%$ in Co-synch +progesterone injection and $33.33 \%$ in double synch protocol. The estrus characteristics like duration of estrus $(14.16+1.07,11.16+1.30 \mathrm{hrs}$.) and estrus grading $(3.5+0.34,3.0+0.25)$ were better in farm reared and traditionally reared ones. The figures for double synch and Co-synch +progesterone treated ones were $12.83+1.01,8.83+0.70$ and $10.83+1.30,11.66+2.39$ respectively in different management groups. The levels of progesterone on 23rd day AI and Estrogen and LH on the day of estrus was higher in all the animals irrespective of treatment. There was no significant difference in pre and post treatment values in glucose and total protein. The phosphorous and calcium ratio was low in most of the animals. The incidence of infertility ranged between 50 to 81.00 per cent in different breeds of animal. It was concluded that estra double synch protocol might be advantageous for HF animals in Odisha for fertility improvement.

\section{Introduction}

India stands first in terms of cattle and buffalo population by possessing about $15-20$ per cent of total world cattle and buffalo population. Livestock forms an integral part of agriculture in India and involves participation of 70 per cent of population, most of which are small or medium scale holders. Reduced fertility or sub-fertility is the most commonly occurring reproductive problems occurring in cattle and buffaloes in India. This problem is severe in rural and sub-urban areas. Subfertility problem affects livestock production and great economic loss to farmer. Sub- fertility is a condition when there is decreased fertility rate resulting due to poor management, low body condition score (BCS), severe climatic stress, pathological condition of ovary and/or reproductive tract, anovulatory estrous, irregular follicular wave pattern, inappropriate timing of artificial insemination (AI) or natural breeding. Among all the factors, irregular cyclicity with anovulatory estrous are the major cause attributing to sub-fertility resulting in severe economic loss. 
Keeping all the facts in mind, the present study on "Fertility improvement in sub-fertile cows by different hormonal protocols with special reference to HF crosses" with different new and improvised hormonal protocols and mineral supplementation is undertaken.

The following are the objectives of the study to record the effect of the therapy in $\mathrm{HF}$ Crosses reared both in organized farm and unorganized sector.

To study the incidence of infertility among HF and other breeds of cattle in western and coastal Odisha. To study the effect different hormonal protocols in induction of fertile estrous. To study the effect of management on effect of hormonal therapy and conception arising thereof.

\section{Materials and Methods}

\section{Place and period of study}

The purposed study was conducted for 1 year and half months from July 2016 to July 2017 in the Department of Animal Reproduction Gynaecology and Obstetrics, College of veterinary science and animal husbandry, OUAT, BBSR in collaboration with AICRP on NPAERPA.

\section{Incidence study}

The study included different villages adopted by the AICRP project in western and coastal Odisha and some established HF dairy farms.

\section{Source of animals}

HF Cows with a history of repeat breeding were considered for the present investigation. Cows owned by farmers in rural condition in Cuttack, western districts of Odisha and organized private sector farms near outskirts of Cuttack and Bhubaneswar primarily constituted the materials for the present experiment. In addition to this some animals owned by private owners in the outskirts of Bhubaneswar were also incorporated in this study. The animals were belonging to rural farmers which were maintained by traditional animal husbandry practices and animals well maintained in organized private farm. The animals were subjected to standard feeding and managemental practices with provision of quality mineral supplement.

\section{Selection of animals}

Among repeat breeder cows of first to 5th parity having more than $300 \mathrm{~kg}$ body weight and not conceiving after three successive AI were considered for the study. Cows with prolonged illness, malnutrition, puerperal diseases and congenital or anatomical deformities of genital organs were excluded from the study.

At the outset, certain preliminary informations regarding breeding history and reproductive status of the animals were ascertained from the owners to serve as a guide line for the present investigation. Repeat breeding due to subclinical infection was ruled out by white side test and late heat per vaginal examination.

\section{White side test}

The uterine discharges were aseptically collected in sterile sheath and syringe and mixed with equal volume of $5 \%$ sodium hydroxide. The mixture was heated up to boiling point for 10 minutes and the intensity of colour changes were studied and graded according to the method of Pateria and Rawal (1990).

Normal - turbid/ no colour

Mild - light yellow colour

Moderate - yellow colour

Severe - dark yellow colour 


\section{Gynaeco-clinical examination}

Internal reproductive organs were examined by inserting lubricated gloved hand. After back racking, the cervix was palpated through the rectal wall on the ventromedial aspect of the pelvic brim. Body of the uterus and uterine horns were palpated by using cervix as guideline on either side of the pelvic brim or in the pelvic cavity. The contour, consistency, tonicity and the patency of the cervix and uterine horns were assessed by careful manipulation and handling. The ovaries were palpated gently after retracting the cervix and uterus cranio-ventral and slightly lateral to the bifurcation of uterine horns. When cradled between middle and index finger, the surface the ovary was explored. The palpation was carried out at the time of grouping.

\section{Functional categorisation of ovary}

The ovaries were classified as under depending upon the size, texture and presence or absence of CL and follicles on its surface.

Non Functional Ovary (NFO) - hard, below 1 $\mathrm{cm}$ dia without $\mathrm{CL}$ and follicles

Sub-active Ovary (SAO) - soft, round with follicle or soft fluctuating area

Functional Ovary (FO) - bigger, firm with CL or RCL

\section{Health care and management of animals}

The village populations of breedable cows were screened from the records of AI Centers and infertile animals were identified through organizing special fertility clinics. As far as possible, apparently healthy pluriparous cows were selected for this study. These animals were managed by the farmers individually at their door-step. Cows in spontaneous or induced oestrus were inseminated using good quality frozen thawed semen by the concerned veterinary technician, and pregnancy was confirmed in non-return cases by per rectal palpation 60 days later. All the infertile buffaloes thus identified were provided with mineral mixture for 2 months @ 50 gms/day.

\section{Progesterone with 7 day Co-synch protocol}

The animals in this group were injected with medroxyprogesterone*** $500 \mathrm{mg}$ depot $\mathrm{i} / \mathrm{m}$ on the day of examination (0 day) along with Inj. of Buserelin acetate**10mcg $\mathrm{i} / \mathrm{m}$ route. Injection of cloprostenol* $500 \mathrm{mcg} \mathrm{i} / \mathrm{m}$ was given after a week (Day 7). Buserelin acetate $^{* *} 10 \mathrm{mcg}$ was repeated after two days i.e. Day 10 (preferably 66 hours of 2nd cloprostenol injection). Fixed time insemination (FTAI) was done at the time of 2nd GnRH injection and repeat AI 12 hours later.

\section{Recording of response to induction protocols}

The following observations were made in the experimental animals after the use of induction protocols.

\section{Estrus response}

It was calculated as per cent of animals responded to treatment with respect to oestrus induction within 25 days of 1 st PG F2 $\alpha$ injection.

\section{Induction interval}

It was calculated from the time of 2nd PG F2 $\alpha$ injection to the exhibition of estrus (in hours).

\section{Duration of estrus}

It was recorded in hours on the basis of internal and external signs as envisaged in the animals and also from interaction with the animal owner. 


\section{Grading of estrus behaviour}

Grading/ rating of estrus was done after evaluating the oestrus behavior of individual animal which is graded from 4 to 1 .

4: Clear, ropy, vaginal discharge, frequent vocalization, motor movement and excitation.

3: All the characteristic of oestrus with less intensity.

2: Clear vaginal discharge with no other behavioral symptoms.

1: None of the external characteristic of oestrus is noticed except cervical relaxation and presence of follicle on per rectal examination.

\section{Insemination}

The animals were inseminated in the induced estrus with good quality frozen semen supplied by ARD Dept. In case of animals inducted with double synch protocol, fixed time insemination was conducted at $16 \mathrm{hrs}$ and $40 \mathrm{hrs}$ of last injection of Buserelin acetate.

Similarly animals inducted with estra double synch protocol were inseminated twice at 48 and $72 \mathrm{hrs}$ of injection of estradiol benzoate.

The control animals were inseminated at estrus following AM-PM rule.

\section{Pregnancy diagnosis}

Pregnancy diagnosis was conducted 60-90 days post insemination by rectal palpation.

\section{Conception rate}

Conception rate was calculated as the percentage of pregnant animals out of the total inseminated animals.

\section{Analysis of data}

Data generated during the present investigation were subjected to statistical analysis as per standard method described by Snedecor and Cochran (1994) and M.M. SAS software; 2011 version 9.3 by SAS Inst. Inc. CARI, NC.

* Gynostart, Bovian, Himmat Nagar, India

** Gynofertin, Bovian, Himmat Nagar, India

***P-Depot, Zydus Animal Health Care, Ahmedabad

\section{Results and Discussion}

Reproductive efficiency is one of the important aspects of dairy production. Both inherited and acquired abnormalities of genital organs can adversely affect fertility. Besides, anatomical or congenital anomalies, functional abnormalities of female gonads are common cause of infertility. Among all delayed maturity in heifers, post-partum anestrus and repeat breeding in cows have been recognized as most prevailing and widespread infertility condition throughout the globe.

Even in well-fed cows with optimum management, endocrine aberration may be a major cause of derangement in the hypothalamo-hypophyseal-gonadal axis and its secretor hormones necessary for attachment of early puberty/sexual maturity in heifers, initiation of post-partum estrus in cows and maintenance of the conceptus. The present study deals with the fertility improvement of HF and HF crosses in Odisha with intervention of a group of exogenous hormones in the form of a protocol(s) to address the condition quickly with high success rate of fertile estrus and succeeding conception. Three new protocols have been used during the study. 
Study of incidence of reproductive disorders

Anestrus and repeat breeding are the most commonly encountered infertility problems which affect directly or indirectly production and reproduction performance of cows. In the present study, various major infertility problems were evaluated in districts of western Odisha and Cuttack district under AICRP project of OUAT.

The frequency of various anestrus condition in different breeds under diversified managemental conditions, were presented in the Table 1. In HF and HF crosses the incidence of anestrus and repeat breeding, subestrus, delayed maturity and reproductive tract infection (RTI) were 30\% (60), $28 \%$ (56), 7\% (14), $11 \% \quad(22)$ and 5\% (10) respectively. The overall incidence was $81 \%$ (162) out of 200 cows. The corresponding values for jersey and jersey crosses were observed to be $17.5 \%$ (35), $20.5 \%$ (41), $7.5 \%$ (15), $8.5 \%$ (17) and $5.5 \%$ (11) respectively, the overall being $59.5 \%$ (119) out of 200 cows surveyed. Correspondingly, in indigenous breeds the incidence was $22 \%$ (22), $14 \%$ (14), $3 \%$ (3), $7 \%$ (7), $4 \%$ (4) respectively with an overall value of $50 \%$ (50) following screening of 100 cows. Out of 500 cows the incidence of anestrus, repeat breeding, subestrus, delayed maturity and RTI irrespective of breeds were $23.4 \%$ (117), $22.2 \%$ (111), 6.4\% (32), 9.2\% (46) and 5\% (25) respectively with an overall percentage of 66.2 (331).

In the present study, three different hormonal protocols were tried in $36 \mathrm{HF}$ cattle reared either in farm conditions or in traditional husbandry to improve their fertility. Parameters like incidence of infertility, biochemical and hormonal status, estrus characteristics and conception rate were calculated. The study revealed the following salient findings.

All the three hormonal protocols provided higher conception rate. However, the estra double synch protocol was proved to be the best followed by double synch and Co-synch+ progesterone injection (Table 2-4).

Table.1

\begin{tabular}{|c|c|c|c|}
\hline \multirow[b]{2}{*}{$\begin{array}{l}\text { Group I } \\
(n=12)\end{array}$} & $\begin{array}{l}\text { Subgroup } A_{1} \\
(n=6)\end{array}$ & $\begin{array}{l}\text { Repeat breeding HF cow } \\
\text { from organized farm }\end{array}$ & Treatment protocols \\
\hline & $\begin{array}{l}\text { Subgroup } B_{1} \\
(n=6)\end{array}$ & $\begin{array}{l}\text { Repeat breeding HF cow } \\
\text { under trad1 rearing }\end{array}$ & $\begin{array}{l}\text { Double Synch protocol (PG-GnRH- } \\
\text { PG-GnRH-FTAI-FTAI on Do, D2, } \\
\text { D9, D11, D11 and D12) }\end{array}$ \\
\hline \multirow{2}{*}{$\begin{array}{l}\text { Group II } \\
(n=12)\end{array}$} & $\begin{array}{c}\text { Subgroup } A_{2} \\
(n=6)\end{array}$ & $\begin{array}{l}\text { Repeat breeding HF cow } \\
\text { from organized farm }\end{array}$ & \multirow{2}{*}{$\begin{array}{l}\text { Estra double Synch protocol (PG- } \\
\text { GnRH-PG-E,-FTAI-FTAI on Do, } \\
\text { D2, D9, D10, D12 and D13) }\end{array}$} \\
\hline & $\begin{array}{l}\text { Subgroup } B_{2} \\
(n=6)\end{array}$ & $\begin{array}{l}\text { Repeat breeding HF cow } \\
\text { under trad1. rearing }\end{array}$ & \\
\hline \multirow{2}{*}{$\begin{array}{l}\text { Group III } \\
(n=12)\end{array}$} & $\begin{array}{l}\text { Subgroup } A_{3} \\
(n=6)\end{array}$ & $\begin{array}{l}\text { Repeat breeding HF cow } \\
\text { from organized farm }\end{array}$ & \multirow{2}{*}{$\begin{array}{l}\text { Progesterone + Co-synch (GnRH- } \\
\text { Progesterone depot inj-PG-GnRH- } \\
\text { FTAI-FTAI on Do, Do, D7, D10, } \\
\text { D10 and D11) }\end{array}$} \\
\hline & $\begin{array}{l}\text { Subgroup } B_{3} \\
(n=6)\end{array}$ & $\begin{array}{l}\text { Repeat breeding HF cow } \\
\text { under trad1 rearing }\end{array}$ & \\
\hline \multirow{2}{*}{$\begin{array}{l}\text { Group IV } \\
(n=12)\end{array}$} & $\begin{array}{l}\text { Subgroup } A_{4} \\
(n=6)\end{array}$ & $\begin{array}{l}\text { Normal cyclic repeating HF } \\
\text { cow from organized farm }\end{array}$ & \multirow{2}{*}{ Norma1 AI on observed estrus } \\
\hline & $\begin{array}{l}\text { Subgroup } \mathrm{B}_{4} \\
(\mathrm{n}=6)\end{array}$ & $\begin{array}{l}\text { Normal cyclic repeating HF } \\
\text { cow from organized farm }\end{array}$ & \\
\hline
\end{tabular}

Figures in the parenthesis indicate the number of animals 


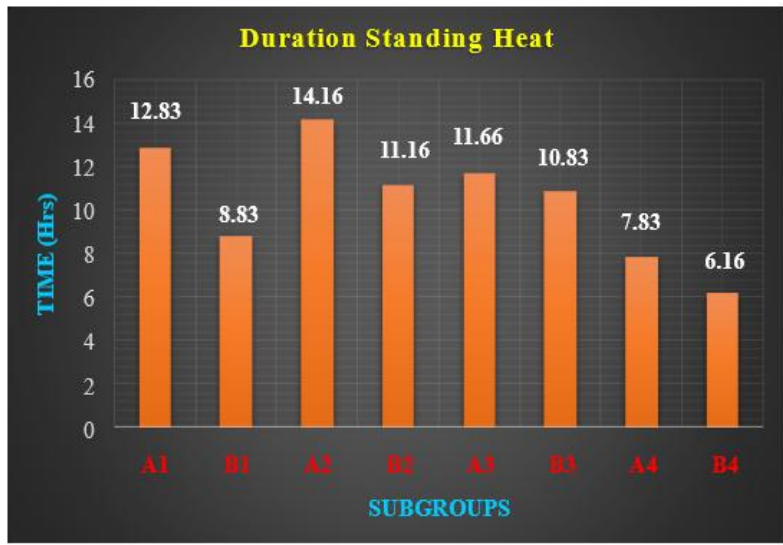

Duration standing heat in different treatment groups and subgroups

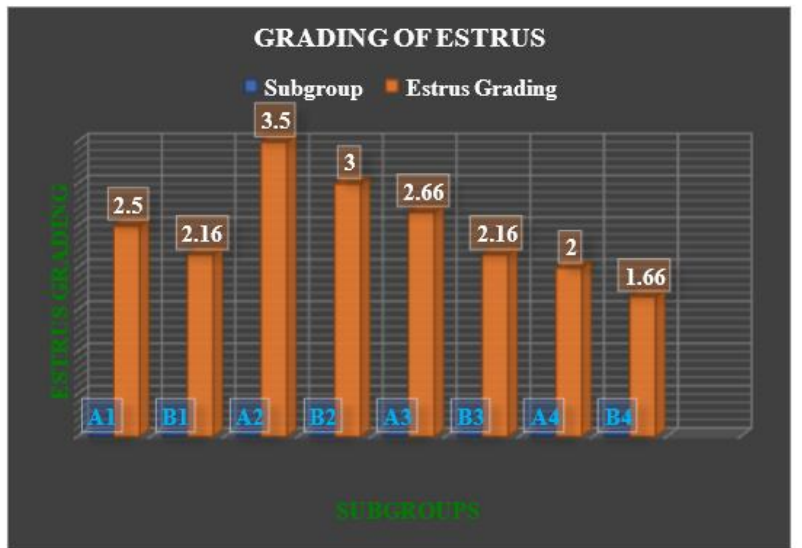

Estrus grading in different groups and subgroups

Table.2

Effect of different hormone treatment protocols on conception rate followed in an organized dairy farm

\begin{tabular}{|c|c|c|c|c|c|}
\hline \multirow{2}{*}{ Protocols } & \multicolumn{2}{|c|}{ Con. Rate } & Overall Con. & Hervices/Conception \\
\cline { 2 - 6 } & Heifer & Cow & & 2.5 \\
\hline GNRH-AI & $20(1 / 5)$ & $28.57(2 / 7)$ & $25(3 / 12)$ & 2.34 \\
\hline PG & $57.14(4 / 7)$ & $60.00(3 / 5)$ & $58.33(7 / 12)$ & 2.1 \\
\hline GPG & $57.14(4 / 7)$ & $71.42(5 / 7)$ & $64.28(9 / 14)$ & 2 \\
\hline DS & $66.66(4 / 6)$ & $80(8 / 10)$ & $75(12 / 16)$ & 2 \\
\hline ES & $75(6 / 8)$ & $77.77(7 / 9)$ & $76.47(12 / 17)$ & 1.75 \\
\hline Control & $33.33(4 / 12)$ & $31.25(5 / 16)$ & $32.14(9 / 28)$ & 2.7 \\
\hline
\end{tabular}

Figures in the parenthesis indicate number of animals

\section{Table.3}

\begin{tabular}{|c|c|c|c|c|c|c|}
\hline \multirow{2}{*}{$\begin{array}{c}\text { Experimental } \\
\text { Group }\end{array}$} & \multirow[b]{2}{*}{ Sub Group } & \multirow{2}{*}{$\begin{array}{l}\text { Number of cows } \\
\text { Responded and } \\
\text { inseminated }\end{array}$} & \multirow{2}{*}{$\begin{array}{l}\text { No. of cows } \\
\text { conceived }\end{array}$} & \multirow{2}{*}{$\begin{array}{l}\text { No. of cows } \\
\text { conceived }\end{array}$} & \multicolumn{2}{|c|}{$\begin{array}{c}\text { First Service } \\
\text { conception rate }(\%) \\
\text { in treatment Groups } \\
(\mathrm{I}+\mathrm{II}+\mathrm{III}) \\
\end{array}$} \\
\hline & & & & & $\begin{array}{c}\text { Farm } \\
\text { Rearing } \\
\mathrm{A}_{1}-\mathrm{A}_{4}\end{array}$ & $\begin{array}{c}\text { Tradl. } \\
\text { Rearing } \\
\mathrm{B}_{1}-\mathrm{B}_{4}\end{array}$ \\
\hline \multirow{2}{*}{ Group-I (n=12) } & $\begin{array}{c}\mathrm{A}_{1} \\
(\mathrm{n}=6)\end{array}$ & 06 & $3(50.00)$ & \multirow[t]{2}{*}{$4(33.33)$} & \multirow{6}{*}{55.55} & \multirow{6}{*}{28.88} \\
\hline & $\begin{array}{c}\mathrm{B}_{1} \\
(\mathrm{n}=6)\end{array}$ & 06 & $1(16.66)$ & & & \\
\hline \multirow{2}{*}{ Group-II ( $\mathrm{n}=12)$} & $\begin{array}{c}\mathrm{A}_{2} \\
(\mathrm{n}=6)\end{array}$ & 06 & $4(66.66)$ & \multirow{2}{*}{$6(50.00)$} & & \\
\hline & $\begin{array}{c}\mathrm{B}_{2} \\
(\mathrm{n}=6)\end{array}$ & 06 & $2(33.33)$ & & & \\
\hline \multirow{2}{*}{ Group-III ( $\mathrm{n}=12)$} & $\begin{array}{c}\mathrm{A}_{3} \\
(\mathrm{n}=6)\end{array}$ & 06 & $3(50.00)$ & \multirow{2}{*}{$5(41.66)$} & & \\
\hline & $\begin{array}{c}\mathrm{B}_{3} \\
(\mathrm{n}=6)\end{array}$ & 06 & $2(33.33)$ & & & \\
\hline \multirow{2}{*}{ Group-IV $(n=12)$} & $\begin{array}{c}\mathrm{A}_{4} \\
(\mathrm{n}=6)\end{array}$ & 06 & $1(16.66)$ & \multirow{2}{*}{$2(16.66)$} & \multirow[t]{2}{*}{16.66} & \multirow[t]{2}{*}{16.66} \\
\hline & $\begin{array}{c}\mathrm{B}_{4} \\
(\mathrm{n}=6)\end{array}$ & 06 & $1(16.66)$ & & & \\
\hline
\end{tabular}

Figures in parenthesis indicate percentage 
Table.4

\begin{tabular}{|c|c|c|c|c|c|c|c|c|c|}
\hline \multirow{2}{*}{ Protocol } & \multicolumn{2}{|c|}{ Induced Estr. Response } & \multirow[t]{2}{*}{ Overall Response } & \multicolumn{2}{|c|}{ Induction interval } & \multicolumn{2}{|c|}{ Estrus behaviour } & \multicolumn{2}{|c|}{ Duration of estrus } \\
\hline & Heifer & Cow & & Heifer & Cow & Heifer & Cow & Heifer & Cow \\
\hline GnRH-AI & & & & & & $1.82 \pm 0.59$ & $2.11 \pm 0.92$ & $7.21 \pm 2.31$ & $8.35 \pm 1.85$ \\
\hline PG & $71.42(5 / 7)$ & $80.00(4 / 5)$ & $75(9 / 12)$ & $61.82 \pm 2.15$ & $56.7 \pm 1.86$ & $2.83 \pm 0.95$ & $2.72 \pm 0.82$ & $7.56 \pm 1.48$ & $8.54 \pm 0.86$ \\
\hline GPG & $57.14(4 / 7)$ & $85.71(6 / 7)$ & $71.42(10 / 14)$ & $65.28- \pm 1.75$ & $57.21 \pm 1.95$ & $3.19 \pm 0.74$ & $2.98 \pm 0.78$ & $9.62 \pm 1.41$ & $10.34 \pm 2.14$ \\
\hline Double synch & $83.33(5 / 6)$ & $90.00(9 / 10)$ & $87.5(14 / 16)$ & $65.82 \pm 1.86$ & $55.89 \pm 2.15$ & $3.08 \pm 0.86$ & $3.16 \pm-0.76$ & $10.24 \pm 2.08$ & $11.32 \pm 2.86$ \\
\hline Estra double synch & $87.5(7 / 8)$ & $88.88(8 / 9)$ & $88.23(15 / 17)$ & $64.72 \pm 1.59$ & $56.98 \pm 1.92$ & $3.26 \pm 0.82$ & $3.38 \pm 0.67$ & $12.95 \pm 1.67$ & $13.85 \pm 1.71$ \\
\hline
\end{tabular}

Figures in the parenthesis indicate number of animals

The estrus response was excellent with more intensity and duration of estrus in estra doublesynch protocol.

The farm reared HF animals responded better than animals reared traditionally.

The serum biochemical profile and hormonal profile differed significantly between these class of animals.

Since the HF animals need more attention in feeding and management than other breeds of animals to countermand the stress due to climate and production, still their fertility can be maintained in Odisha condition by employing suitable hormonal protocol.

The glucose and total protein level did not differ much among groups.

The level of Estrogen and LH on the day of estrum was found to be maximum, the progesterone level was more at 23 days post insemination in all the treatment groups.

Level of calcium, phosphorous and $\mathrm{Ca}$ : $\mathrm{P}$ ratio was lower in most of the animals.
It can be concluded that estra double synch and double synch protocols might be of value to improve fertility in $\mathrm{HF}$ animals.

\section{References}

Acosta, T. J., Yoshizawa, N., Ohtani, M., and Miyamoto, A. (2002). Local changes in blood flow within the early and midcycle corpus luteum after prostaglandin F2 $\alpha$ injection in the cow. Biology of Reproduction, 66(3): 651658.

Ali, A., and Fahmy, S. (2007). Ovarian dynamics and milk progesterone concentrations in cycling and noncycling buffalo-cows (Bubalus bubalis) during Ovsynch program. Theriogenology, 68(1): 23-28.

Barros CM, Moreira MBP, Figueiredo RA, Teixeira AB and Trinca LA. 1999. Synchronization of Ovulation in Beef Cows (BosIndicus) Using GnRH, PGF $2 \alpha$ and Estradiol Benzoate, Theriogenology, 9(3): 139-152.

Bhat, F.A., Bhattacharyya, H.K. and Khan, M.Z. (2012). Studies on prevalence of repeat breeding in crossbred cattle of 
Kashmir valley. Indian J. Anim. Res., 46(3): 306-309.

Butani MG, Dhami AJ and Rajesh Kumar. 2011. Comparative blood profile of progesterone, metabolites and minerals in anestrous, subestrous, repeat breeding and normal cyclic buffaloes. Indian $\mathrm{J}$. Field Vets., 7(2): 20-24

Chandrakar D, Tiwary RP, Awasthi MK and Hirpurkr SD. 2003. Serum biochemical profile of repeat breeder crossbred cows. Indian J. Anim. Reprod., 4(2): 125127.

Dhabale RB and Sharma NC. 1999. Incidence of repeat breeding at an organised crossbred cattle farm. XV Annual convention and National Symposium, ISSAR, Ludhiana, Feb 10-12, S.N. 91, pp. 64.

Ekrami, B., Kordjazy, S., Rahmani, J., Ghasemzade, H. and Tajik, P. (2008). Assessment of Ovsynch and CIDR protocols on pregnancy rate of North Iranian buffaloes in low breeding season. Proc. 25th World Buiatrics Congr, Budapest, Hungary, p. 141.

Grummer RR and Carroll DJ. 1988. A review of lipoprotein cholesterol metabolism: importance to ovarian function, Journal of Animal Science, 66: 3160-3173

Hamphrey WD, Kaltenbach CC, Dunn TG, Koritnik DR and Niswender GD. 1983. Characterisation of hormonal patterns in the beef cows during postpartum anestrus. Journal of Animal Science, 56: 445-453.

Macmillan KL and Henderson HV. 1984. Analyses of the variation in the interval from an injection of prostaglandin $\mathrm{F} 2 \mathrm{a}$ to oestrus as a method of studying patterns of follicle development during dioestrus in dairy cows, Animal. Reproduction Science, 6: 245.

Muneer, S., Sadasiva Rao, K. and Solmaon Raju, K.G., 2009. Efficacy of GnRHPGF2 $\alpha-$ GnRH, PMSG and PMSG + hCG in postpartum anestrous crossbred cows, Indian Journal of Animal Reproduction, 30: 7-9.

\section{How to cite this article:}

Raju, H., S. Munda and Mishra, P.C. 2018. Fertility Improvement in Subfertile Cows by Different Hormonal Protocols in Special Reference to HF Crosses. Int.J.Curr.Microbiol.App.Sci. 7(06): 986-993. doi: https://doi.org/10.20546/ijcmas.2018.706.116 